\title{
Clinical Hemorheology
}

\section{CONTENTS AND AUTHOR INDEX}

\section{FOR VOLUME 14, 1994}

\author{
Editors-in-Chief \\ SIEGFRIED WITTE \\ Medizinische Abteilung, Diakonissen-Krankenhaus \\ Diakonissenstr. 28, D-76199 Karlsruhe, Germany
}

\author{
JEAN-FRANÇOIS STOLTZ \\ Hémorhéologie - Hématologie \\ Faculté de Médecine, Brabois B.P. 184 \\ F-54505 Vandoeuvre lès Nancy, France
}

Founded by A.L. Copley

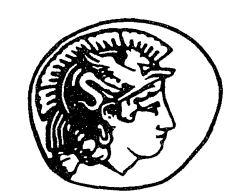

PERGAMON 


\title{
Clinical Hemorheology
}

\author{
A Companion Journal of 'Biorheology'
}

\section{An Official Journal of the International Society of Biorheology, An Affiliated Commission of the International Union for Pure and Applied Biophysics}

Founded by A.L. Copley

\section{Editors-in-Chief}

SIEGFRIED WITTE, Medizinische Abteilung, Diakonissen-Krankenhaus, Diakonissenstr. 28, D-76199 Karlsruhe, Germany, FAX: +497218893044

JEAN-FRANÇOIS STOLTZ, Hémorhéologie - Hématologie, Faculté de Médecine, Brabois B.P. 184, F-54505 Vandoeuvre lès Nancy, France. FAX: +33 83592643

\section{Board of Editors}

O.K. BASKURT, Antalya, Turkey

M.R. BOISSEAU, Pessac, France

T. DI PERRI, Siena, Italy

A.M. EHRLY, Frankfurt, Germany

E. ERNST, Exeter, UK

M.R. HARDEMAN, Amsterdam, Netherlands

Y. ISOGAI, Tokyo, Japan

M. KAIBARA, Chiba, Japan

P.L. LA CELLE, Rochester, NY, USA

H. LECHNER, Graz, Austria

F. LIAO, Beijing, China

G.D.O. LOWE, Glasgow, UK

D.E. McMILLAN, Tampa, FL, USA
H.J. MEISELMAN, Los Angeles, CA, USA

G.B. NASH, Birmingham, UK

G. POTRON, Reims, France

M. RAMPLING, London, UK

R.J. RASIA, Rosario, Argentina

R.K. REED, Bergen, Norway

W.H. REINHART, Chur, Switzerland

P. SALDANHA, Lisbon, Portugal

H. SCHMID-SCHÖNBEIN, Aachen, Germany

T. SOMER, Helsinki, Finland

J.-L. WAUTIER, Paris, France

F.Y. ZHUANG, Beijing, China

PRODUCTION EDITOR: Doug Cherno, E-MAIL: D.CHERNO@ELSEVIER.COM.

CLINICAL HEMORHEOLOGY EXECUTIVE EDITORIAL OFFICE: Siegfried Witte, Executive Director, Medizinische Abteilung, Diakonissen-Krankenhaus, Diakonissenstr. 28, D-76199 Karlsruhe, Germany, FAX: +49 7218893044

PUBLISHING, SUBSCRIPTION AND ADVERTISING OFFICES: Elsevier Science Inc, 660 White Plains Road, Tarrytown, NY 10591-5153, U.S.A., E-MAIL ADDRESS: ESUK.USA@ELSEVIER.COM; or Elsevier Science Ltd, The Boulevard, Langford Lane, Kidlington, Oxford, OX51GB, England.

PUBLISHED BIMONTHLY. Annual Institutional Subscription Rate (1995): North, Central and South America, US\$522.00, Rest of World $£ 350.00$. Sterling prices exclude VAT. Non-VAT registered customers in the European Community will be charged the appropriate VAT in addition to the price listed. Prices include postage and insurance and are subject to change without notice. 


\section{CLINICAL HEMORHEOLOGY}

VOLUME 14, NUMBER 1

JANUARY-FEBRUARY 1994

\section{CONTENTS}

S. Witte and J.-F. Stoltz

S. Witte

S. Witte

H.-P. Haring, P. Pohl, W. Schimetta, W. Pölz and F. Aichner

M.R. Boisseau, P. Dufourcq, M. Seigneur, M.F. Roudaut and A. Bertrand

M. Walzl, H. Valetitsch, B. Walzl and H. Lechner

M. Walzl, B. Walzl, G. Kleinert, G. Schied and $\mathrm{H}$. Lechner

B. Walzl, A. Haas, M. Walzl, J. Faulbom, G.E. Sochor, H. Eckhardt, J. Berglöff and H. Lechner

N. Maeda and T. Shiga

C. Zoukourian and J.-L. Wautier

A. Muñoz, J. Uberos, A. Bonillo, A. Valenzuela, A. Puertas, E. Narbona, R. Sanchez and

J.A. Molina
1 Editorial

3 Obituary: Hellmut Hartert (1918-1993)

7 Obituary: Alexander Silberberg (1923-1993)

Conference Communications

Proceedings of the First International and Eighth

European Conference on Clinical Hemorheology, Vienna, Austria, 5-8 July 1993 - Part III

Free Session: Hemodilution

11 Hydroxyethylstarch - influence of molar substitution on haemorheologic parameters: a clinical double blind study

Symposium: Hemorheology in cerebrovascular disease

19 Changes in cell behaviour during ischaemic cerebrovascular disease

27 Improved cerebral blood flow in patients treated by a single heparin-induced extracorporeal LDL precipitation (HELP)

Symposium: Plasmapheresis: HELP

37 LDL-precipitation and its influence on haemorheology and clinical symptoms in acute stroke and cerebral multiinfarct disease

45 First experiences with heparin-induced extracorporeal LDL precipitation (HELP) in oculary microcirculatory disturbances

Proceedings of the Eighth International Congress of Biorheology, Yokohama, Japan, 3-8 A ugust 1992 - Part IV

Symposium: Erythropoietin: Hemorheology and Hemodynamics

53 Effect of recombinant human erythropoietin on blood rheology of rat

Non-Conference Communications

Review Article

63 Cellular abnormalities in diabetes mellitus as factors in vascular complications

Papers

75 Plasma and internal erythrocyte viscosity in umbilical artery and vein of premature infants with and without acute asphyxia 
M.F. Berthault, A. Othmane, J. Guillou J.L. Counord, A. Ktorza and J. Dufaux

C.R. Welch, M.W. Rampling, M.A. Anwar, D.G. Talbert and C.H. Rodeck

J. F. Brun, I. Supparo, C. Fons, A. El Bouhmadi and A. Orsetti

H. Hammi, P. Perrotin, R. Guillet and M. Boynard

M. Mukherjee

M. Mukherjee

S. Kleinschmidt and U.T. Seyfert

N.H. Schut
83 Hemorheological abnormalities in rats with experimental mild diabetes: improving effect of troxerutine and $\alpha$-tocopherol

93 Gestational reference ranges for fetal haemorheological parameters

105 Low values of blood viscosity and erythrocyte aggregation are associated with lower increases in blood lactate during submaximal exercise

117 Determination of red blood cell aggregation in young and elderly subjects evaluated by ultrasound (Influence of dihydroergocryptine mesylate)

Brief Communications

127 Alpha-2-macroglobulin and coronary heart disease

131 Correlation of mean corpuscular volume of red cells with membrane choline-phospholipid-to-aminophospholipid ratio

137 A diagnostic and therapeutic approach to heparin associated thrombocytopenia (HAT)

Dissertation Abstract

141 Rheological aspects in diabetic patients \& renal transplant recipients

145 Announcement

146 Contents of Biorheology

Volume 30, Numbers $3 / 4$

\section{CLINICAL HEMORHEOLOGY}

VOLUME 14, NUMBER 2

MARCH-APRIL 1994

\section{CONTENTS}

S. Witte and J.-F. Stoltz

J.G. Jones, R.A. Adams and S.-A. Evans

M.R. Boisseau, E. Mazoyer, L. Ripoll and L. Drouet

P. Lechner, M. Walzl and B. Walzl
$147 \quad$ Editorial

Review Article

149 Bulk filtration through micropore membranes for analysing blood cell rheology in clinical research

Conference Communications

Proceedings of the First International and Eighth European Conference on Clinical Hemorheology, Vienna, Austria, 5-8 July 1993 - Part IV

Symposium:

171 Hemorheologically active substances, their profile and clinical impact

Symposium: Plasmapheresis: HELP

181 The impact of H.E.L.P. on haemorheology in peripheral arterial disease 
F. Jung, J. Koscielny, C. Mrowietz, G. Pindur, H. Förster, W. Schimetta, H. Kiesewetter and $\mathrm{E}$. Wenzel

E. Tozzi, M.G. Tozzi-Ciancarelli, C. Di Massimo, A. Mascioli, T. Gentile and F. de Matteis

A. Luquita, A. Dominighini, R. Rasia and M. Rasia

M. Mukherjee and A.P. Desa

P. Ruef, E.P. Zilow and O. Linderkamp

X. Wang and J.-F. Stoltz

P. Kent, G. Williams and R. C. Kester

M. Boynard, F. Ribier, R. Guillet, F. Driss, P. Perrotin, F. Gaudey, C. Pautou and B. Nalpas

H. Landgraf, D. Schulte-Huermann and A.M. Ehrly

M.V. Kulkarni and R.R. Puniyani

Wen Zong-yao, Tao Zu-lai, Ma Wei-yuan, Sun Da-gong and Li Tian-xun

\section{G. Mchedlishvili}

Free Session: Hemodilution

189 Elimination kinetics of different hyrdoxyethyl starches and effects on blood fluidity

Non-Conference Communications

Papers

203 Hemorheological parameters and body weight loss in obese children

213 Erythrocyte rheology in standarized experimental chronic renal failure

223 Evaluation of platelet aggregability by computerised probit analysis

233 Deformability of peripheral immature and mature neutrophils

237 Characterization of pathological bloods with a new rheological relationship

245 The effect of acute hand vibration on red cell filterability

255 Assessment of red blood cell deformability in healthy adult subjects: Influence of sex, age, cigarette smoking, menstrual cycle and oral contraceptives

263 Muscle tissue oxygen pressures in healthy volunteers during acute exposure to hypoxia

271 Study of hemorheological parameters in maturity onset diabetic cases

Brief Communication

279 The influence of surface charge of RBC membrane upon RBCs orientation in a shear flow field of low viscosity

Letter to the Editors-in-Chief

Principle factors deranging blood rheological properties in microvessels

Abstracts

287 Abstracts of papers presented at the Congress of the French Society of Fundamental and Clinical Biorheology 3-4 June, 1993 San Malo, France

Announcements

299 17th World Congress of the International Union of Angiology London (UK) 3-7 April, 1995

301 Royal College of Physicians of Edinburgh Second International Symposium on Fibrinogen and Cardiovascular Disease 1-2 November, 1994

302 Contents of Biorheology Volume 30, Numbers 5/6 


\section{CLINICAL HEMORHEOLOGY}

VOLUME 14, NUMBER 3

MAY-JUNE 1994

\section{CONTENTS}

J.P. Isbister

R.R. Puniyani, V.S. Agashe,

H.S. Kudrimoti, A. Fernandez

S. Rao, R. Merchant and S. Phadke

K. Toth, T. Habon, I. Horvath, B. Mezey,

I. Juricskay and Gy Mozsik

W. Oder, B. Oder, H. Kollegger, J. Spatt,

K. Zeiler, S. Aull, M. Mraz and P. Wessely

V. Lipovac and M. Gavella

H. Kiesewetter, A. Birk, F. Jung and H. Radtke

D. Yova, M. Haritou and D. Koutsouris

S.P.M. Crouch, E.M. Saihan and J. Fletcher

G. Caimi, R. Lo Presti, M. Montana, B. Canino,

G. Ventimiglia, A. Catania and A. Sarno

A. Chabanel and Meyer M. Samama

C. Allegra, A. Carlizza, A. Mari

and R. Sarcinella

A. Vayá, M. Martínez, V. Moreno and J. Aznar

Submitted by D. Lerche
Review Article

305 Blood volume, hematocrit and hemorheology:

The interrelationships

Non-Conference Communications

Papers

321 Blood viscosity profiles in polycythemia: Neonatal polycythemia

329 Hemorheological and hemodynamical parameters in patients with ischemic heart disease at rest and at peak exercise

339 Hemorheologic dysfunction in analgesic-induced chronic headache? Results of a pilot study

347 Rheological action of gangliosides on human erythrocytes.

355 Effects of felodipine on the arterial blood pressure and fluidity of blood in patients with arterial hypertension WHO stage I

369 Antagonistic effects of epinephrine and helium-neon (He-Ne) laser irradiation on red blood cells deformability

379 Effect of ingested pentoxifylline on the ex vivo neutrophil function of patients with varicose leg ulcers

393 Platelet membrane fluidity, platelet membrane lipid pattern and platelet cytosolic $\mathrm{Ca}^{2+}$ content in subjects with vascular atherosclerotic disease

401 Evaluation of a method to assess plasma viscosity: The falling ball viscometer

413 Long-term infusional and oral therapy with pentoxiphylline in peripheral vasculopathy: A 3-year follow-up

Letter to the Editors-in-Chief

419 Erythrocyte deformability in patients with primary hypertriglyceridemia

Abstracts

421 Of presentations at the Euromech Colloqium 311 "Blood-Wall Interaction," 18-20 October 1993, Berlin, Germany 

$455 \quad$ First China-France International Symposium of Biorheology
457 9th International Congress of Biorheology and 2nd International Conference on Clinical Hemorheology
459 XXIInd Annual Conference of the Internationa Society on Oxygen Transport to Tissue
461 Contents of Biorheology Volume 31, Number 1

\section{CLINICAL HEMORHEOLOGY}

\section{CONTENTS}

Liao Fu-long

D.E. McMillan

D.E. McMillan and J.I. Malone

Y. Missirlis and V. Kaleridis

S. Chen, G. Barshtein, B. Gavish, Y. Mahler and S. Yedgar

S. Kawakami, Y. Isogai, J. Yamamoto T. Maeda, S. Ikemoto and M. Kaibara

T. Murata

M.W. Rampling and M.J. Pearson
Review Article

463 Treatment of blood stasis syndrome and hemorheology

Conference Communications

Proceedings of the First International and Eighth European Conference on Clinical Hemorheology Vienna, Austria, 5-8 July 1993 - Part V

Symposium: Diabetic Hemorheology

473 Blood viscosity and plasma proteins influencing it are increased in Type I diabetes in the DCCT

481 Hemorheological effects of intensive diabetes management in the DCCT

489 Polymorphonuclear leukocyte deformability in Type II diabetes mellitus and in ageing

Symposium: Red Cell Aggregation

497 Monitoring of red blood cell aggregability in a flow-chamber by computerized image analysis

509 Rheological study on erythrocyte aggregation with special reference to ESR - Application to quick estimation of ESR value -

519 Theoretical analysis of flow properties of aggregating red cell suspensions in narrow horizontal tubes

531 Enzymatic degradation of the red cell surface and its effect on Rouleaux formation 


\section{CLINICAL HEMORHEOLOGY}

VOLUME 14, NUMBER 4

JULY-AUGUST 1994

(Continued from outside back cover)

S.M. MacRury, S.E. Lennie, K.R. Paterson, C.G. Semple and G.D.O. Lowe

J.C. Ellory, S.J. Culliford, E.R. Horwitz, F.B.O. Mojiminiyi and J. Stuart

N. Uyesaka, S. Hasegawa, T. Nakamura, A.T. Hongo, A.N. Schechter and H. Shio

S. Hasegawa, T. Nomura, M. lino, H. Shio, A.N. Schechter and N. Uyesaka

J. Uberos, A. Muñoz, A. Valenzuela, A. Molina, C. Ruiz and G. Galdó

O.K. Başkurt, M. Edremitlioğlu and A. Temiz

G. Caimi, R. Lo Presti, M. Montana; B. Canino and A. Sarno

M.R. Hardeman, P.T. Goedhart, J.G.G. Dobbe and K.P. Lettinga

M.R. Hardeman, P.T. Goedhart and N.H. Schut

E. Fukada
Non-Conference Communications

Papers

539 Deformability of leucocyte subpopulations in Type I (insulin-dependent) and Type II (non-insulin-dependent) diabetic patients

545 Oxpentifylline-induced inhibition of calcium entry into human erythrocytes

557 Pathophysiologic significance of mechanical fragility of red blood cells

571 Causal role of dense microspherocytes in the anemia of hereditary spherocytosis: Clinical importance of filterability measurements through $3-\mu \mathrm{M}$ pores

Rheological behaviour of neonatal blood at term with or without polycythemia: A study in $0.38 \mathrm{~mm}$ diameter tubes

591 In vitro effects of in vivo activated leukocytes on RBC filterability and lipid peroxidation

597 Vascular atherosclerotic disease: Evaluation of white blood cell rheology and metabolism after acute intravenous administration of defibrotide

605 Laser-assisted optical rotational cell analyser (L.O.R.C.A.); I. A new instrument for measurement of various structural hemorheological parameters

619 Laser-assisted optical rotational cell analyser (L.O.R.C.A.); II. Red blood cell deformability: Elongation index versus cell transit time

\section{Book Review}

631 Reports on Progress in Polymer Physics in Japan

\section{Announcements}

633

Euroconference ETRO

635 IXth European Conference on Clinical Haemorheology

636 Contents of Biorheology

Volume 31, Number 2 


\section{CLINICAL HEMORHEOLOGY}

\section{CONTENTS}

J.F. Brun, A. El Bouhmadi, P. Boulot, O. Rousseau, F. Laffargue, J.L. Viala and A. Orsetti

J.F. Brun, P. Boulot, O. Rousseau, A. El Bouhmadi, F. Laffague, J.L. Viala and A. Orsetti

P.C. Buchan

P. Ruef and O. Linderkamp

R.G. Yoa, C. Corda, J.R. Rapin, L. Santona H. Goudonnet, G. Rifle, A. Escousse,

R.C. Truchot and J. Mounie

C.G. Gustavsson, S.U. Persson, H. Larsson and S. Persson

Md. A. Hussain, R.R. Puniyani and S. Kar

M.A. Anwar and M.W. Rampling

F. Laghi Pasini, C. Frigerio, L. De Giorgi, L. Domini, S. Pecchi, P. Damiani, A. Acciavatti, P.L. Capecchi, N. Sodi, T. Provvedi, L. Volpi and T. Di Perri

W.J. Wong, H.H. Hu, Y.O. Luk and Y.K. Lo
Conference Communications

Proceedings of the First International and Eighth European Conference on Clinical HemorheologyVienna, Austria 5-8 July 1993 - Part VI

Symposium: Free Session -

Gynecology and Neonatology

637 Evaluation of erythrocyte hyperaggregation in fetal blood drawn by cordocentesis as a marker of fetal diseases

643 Modifications of erythrocyte aggregation during labor and delivery

651 Fetal deja vu of adult disease - haemorheological associations between fetal intrauterine growth retardation and adult hypertension

659 Plastic deformation of erythrocyte membrane in full-term neonates and adults

Non-Conference Communications Papers

663 Hemorheological benefits of omega-3 polyunsaturated fatty acids on erythrocyte deformability in renal transplanted patients

677 Blood viscosity in relation to blood haemoglobin concentration in healthy subjects and in patients with different cardiovascular diseases

685 Quantification of blood viscosity using power law model in cerebrovascular accidents and high risk controls

697 Comparative hemorheology of five healthy, ethnically diverse groups: Results of a pilot study

709 Effect of adenosine I.V. infusion on peripheral haemodynamics, haemorheology and platelet behaviour in man

723 The follow-up study of blood viscosity in the patients with acute ischemic stroke 
Dissertation Abstracts

S. Persson

VOLUME 14, NUMBER 6

\section{CLINICAL HEMORHEOLOGY}

Erythrocyte deformability studied by viscometry and filtrometry

Announcements

733 Call for sending in dissertations, book (chapters), etc. - M.R. Hardeman

735 17th World Congress of the International Union of Angiology (London 3-7 April 1995)

738 Contents of Biorheology Volume 31, Number 3

NOVEMBER-DECEMBER 1994

\section{CONTENTS}

G. Potron, P. Nguyên and B. Pignon

G.J. Streekstra, J.J. Zwaginga,

E.J. Nijhof, J.J. Sixma

and R.M. Heethaar

Fu-Zhong Qin and Rong-Rui Zhao

X. Wang and J.-F. Stoltz

V. Turchetti, C. De Matteis, F. Leoncini,

F. Picciolini, L. Trabalzini,

M. Guerrini, and S. Forconi

J.F. Brun, J.P. Micallef and A. Orsetti

M.J. Navarro-Prigent, E. Rabetafika,

O. Bournier, P. Boivin and D. Dhermy

S.U. Persson and P. Hedner

H. Lechner, R. Schmidt, B. Reinhart,

P. Grieshofer, M. Koch, F. Fazekas,

K. Niederkorn, S. Horner, A. Irmler and

W. Fried
Review Article

739 Fibrinogen, arterial risk factor, in clinical practice

Non-Conference Communications

Papers

769 The relation between blood viscosity and plasma viscosity in the nephrotic syndrome

779 Effects of reduced red cell deformability on coronary hemodynamics and cardiac function

789 Influence of non-Newtonian properties of blood on the global transport of red blood cells

797 Action of Pentoxifylline on cytosolic calcium and on the erthrocytic morphology during ageing

807 Hemorheologic effects of light prolonged exercise

819 Effect of okadaic acid on the rheological properties of human erythrocyte membranes

831 A filtrometric study on red blood cells after storage in frozen form

841 The Austrian stroke prevention study: Serum fibrinogen predicts carotid atherosclerosis and white matter disease in neuorologically asymptomatic individuals 
Abstracts

Submitted by Shi Yong-De

Submitted by G. Jones

Submitted by S. Hasegawa
847 '94 Chinese National Congress of Clinical Hemorheology and Medical Biophyico-Chemistry

855 Abstracts of papers presented at the Meeting of the Royal Society Forum on Clinical Haemorheology

861 17th Annual Meeting of the Japanese Society of Biorheology

Announcements

865 First Announcement of the 2nd International Conference on Medical Biorheology - Shanghai, China, 1995 - Satellite Conference of the 9th International Congress of Biorheology and 2nd International Conference on Clinical Hemorheology, Big Sky, Montana, U.S.A., 1995

867 Contents and Author Index for Volume 14, 1994

883 Contents of Biorheology Volume 31, Number 4

\section{CLINICAL HEMORHEOLOGY}

\section{MICROCIRCULATION AND MICROPHARMACOLOGY}

\section{CONTENTS}

M.R. Boisseau, Guest Editor

M. Seigneur, C. Closse, J. Constans,

B. Lestage, P. Dufourcq, A. Pruvost,

J. Amiral, C. Conri and M.R. Boisseau

J.R. Domange, S. Bougaret and L. Yubero

R. Baurain, G. Dom and A. Trouet

E. Bouskela and F.Z.G.A. Cyrino

V.M. Miller, K. Rud and P. Gloviczki iii Foreword - Microcirculation and micropharmacology: Towards a new concept

S1 Vascular endothelial cells during hypoxia

S7 Pharmacological studies of Cyclo 3 Fort and its constituents (Ruscus extract, hesperidin methyl chalcone, ascorbic acid): An up-to-date review

S15 Protecting effect of Cyclo 3 Fort and its constituents for human endothelial cells under hypoxia

Possible mechanisms for the effects of Ruscus extract on microvascular permeability and diameter

S37 Interactions of Ruscus-extract with endothelinreceptors in human varicose veins 
V. Wienert

C. Le Dévéhat, T. Khodabandehlou, M. Vimeux and M. Dougny

H. Kiesewetter, F. Jung, M. Jünger, U. Marx and J. Koscielny
S47 The measurement of capillary permeability using computer-aided capillary resistometry

S53 The effects of Cyclo 3 Fort treatment on hemorheological disturbances during a provoked venous stasis in patients with chronic venous insufficiency

Chronic venous insufficiency: Only a macro- or also a microangiopathy? 
Acciavatti, A., 709

Adams, R.A., 149

Agashe, V.S., 321

Aichner, F., 11

Allegra, C., 413

Amiral, J., S1

Anwar, M.A., 93, 637

Aull, S., 339

Aznar, J., 419

Barshtein, G., 497

Başkurt, O.K., 591

Baurain, R., S15

Berglöff, J., 45

Berthault, M.F., 83

Bertrand, A., 19

Birk, A., 355

Boisseau, M.R., 19, 171, Siii, S1

Boivin, P., 819

Bonillo, A., 75

Bougaret, S., S7

Boulot, P., 637, 643

Bournier, O., 819

Bouskela, E., S23

Boynard, M., 117, 255

Brun, J.F., 105, 637, 643, 807

Buchan, P.C., 651

Caimi, G., 393, 597

Canino, B., 393, 597

Capecchi, P.L., 709

Carlizza, A., 413

Catania, A., 393

Chabanel, A., 401

Chen, S., 497

Closse, C., S1

Conri, C., S1

Constans, J., S1

Corda, C., 663

Counord, J.L., 83

Crouch, S.P.M., 379

Culliford, S.J., 545

Cyrino, F.Z.G.A., S23

Da-gong, S., 279

Damiani, P., 709

De Giorgi, L., 709

De Matteis, C., 797 de Matteis, F., 203

Desai, A.P., 223

Dhermy, D., 819

Di Massimo, C., 203

Di Perri, T., 709

Dobbe, J.G.G., 605

Dom, G., S15

Domange, J.R., S7

Domini, L., 709

Dominighini, A., 213

Dougny, M., S53

Driss, F., 255

Drouet, L., 171

Dufaux, J., 83

Dufourcq, P., 19, S1

Eckhardt, H., 45

Edremitlioğlu, M., 591

Ehrly, A.M., 263

El Bouhmadi, A., 105, 637, 643

Ellory, J.C., 545

Escousse, A., 663

Evans, S.-A., 149

Faulborn, J., 45

Fazekas, F., 841

Fernandez, A., 321

Fletcher, J., 379

Fons, C., 105

Forconi, S., 797

Förster, H., 189

Friedl, W., 841

Frigerio, C., 709

Fu-long, L., 463

Fu-Zhong, Q., 779

Fukada, E., 631

Galdó, G., 585

Gaudey, F., 255

Gavella, M., 347

Gavish, B., 497

Gentile, T., 203

Gloviczki, P., S37

Goedhart, P.T., 605, 619

Goudonnet, H., 663

Grieshofer, P., 841

Guerrini, M., 797

Guillet, R., 117, 255
Guillou, J., 83

Gustavsson, C.G., 677

Haas, A., 45

Habon, T., 329

Hammi, H., 117

Hardeman, M.R., 605, 619

Haring, H.-P., 11

Haritou, M., 369

Hasegawa, S., 557, 571, 861

Hedner, P., 831

Heethaar, R.M., 769

Hongo, A.T., 557

Horner, S., 841

Horvath, I., 329

Horwitz, E.R., 545

Hu, H.H., 723

Hussain, Md.A., 685

Iino, M., 571

Ikemoto, S., 509

Irmler, A., 841

Isbister, J.P., 305

Isogai, Y., 509

Jones, G., 855

Jones, J.G., 149

Jung, F., 355, 189, S65

Jünger, M., S65

Juricskay, I., 329

Kaibara, M., 509

Kalerdis, V., 489

Kar, S., 685

Kawakami, S., 509

Kent, P., 245

Kester, R.C., 245

Khodabandehlou, T., S53

Kiesewetter, H., 355, 189, S65

Kleinert, G., 37

Kleinschmidt, S., 137

Koch, M., 841

Kollegger, H., 339

Koscielny, J., 189, S65

Koutsouris, D., 369

Ktorza, A., 83

Kudrimoti, H.S., 321

Kulkarni, M.V., 271

Laffargue, F., 637, 643 
Laghi Pasini, F., 709

Landgraf, H., 263

Larsson, H., 677

Le Dévéhat, C., S53

Lechner, H., 27, 37, 45, 841

Lechner, P., 181

Lennie, S.E., 539

Leoncini, F., 797

Lerche, D., 421

Lestage, B., S1

Lettinga, K.P., 605

Linderkamp, O, 233, 659

Lipovac, V., 347

Lo Presti, R., 393, 597

Lo, Y.K., 723

Lowe, G.D.O., 539

Luk, Y.O., 723

Luquita, A., 213

MacRury, S.M., 539

Maeda, N., 53

Maeda, T., 509

Mahler, Y., 497

Malone, J.I., 481

Mari, A., 413

Martínez, M., 419

Marx, U., S65

Mascioli, A., 203

Mazoyer, E., 171

Mchedlishvili, G., 285

McMillan, D.E., 473, 481

Merchant, R., 321

Mezey, B., 329

Micallef, J.P., 807

Miller, V.M., S37

Missirlis, Y., 489

Mojiminiyi, F.B.O., 545

Molina, A., 585

Molina, J.A., 75

Montana, M., 393, 597

Moreno, V., 419

Mounie, J., 663

Mozsik, Gy., 329

Mraz, M., 339

Mrowietz, C., 189

Mukherjee, M., 127, 131, 223
Muñoz, A., 75, 585

Murata, T., 519

Nakamura, T., 557

Nalpas, B., 255

Narbona, E., 75

Navarro-Prigent, M.J., 819

Nguyên, P., 739

Niederkorn, K., 841

Nijhof, E.J., 769

Nomura, T., 571

Oder B., 339

Oder, W., 339

Orsetti, A., 105, 637, 643, 807

Othmane, A., 83

Paterson, K.R., 539

Pautou, C., 255

Pearson, M.J., 531

Pecchi, S., 709

Perrotin, P., 117, 255

Persson, S., 677, 731

Persson, S.U., 677, 831

Phadke, S., 321

Picciolini, F., 797

Pignon, B., 739

Pindur, G., 189

Pohl, P., 11

Pölz, W., 11

Potron, G., 739

Provvedi, T., 709

Pruvost, A., S1

Puertas, A., 75

Puniyani, R.R., 271, 321, 685

Rabetafika, E., 819

Radtke, H., 355

Rampling, M.W., 93, 531, 697

Rao, S., 321

Rapin, J.R., 663

Rasia, M., 213

Rasia, R., 213

Reinhart, B., 841

Ribier, F., 255

Rifle, G., 663

Ripoll, L., 171

Rodeck, C.H., 93

Roudant, M.F., 19
Rousseau, O., 637, 643

Rud, K., S37

Ruef, P., 233, 659

Ruiz, C., 585

Saihan, E.M., 379

Samama, M.M., 401

Sanchez, R., 75

Santona, L., 663

Sarcinella, R., 413

Sarno, A., 393, 597

Schechter, A.N., 557, 571

Schied, G., 37

Schimetta, W., 11, 189

Schmidt, R., 841

Schulte-Huermann, D., 263

Schut, N.H., 141, 619

Seigneur, M., 19, S1

Semple, C.G., 539

Seyfert, U.T., 137

Shiga, T., 53

Shio, H., 557, 571

Sixma, J.J., 769

Sochor, G.E., 45

Sodi, N., 709

Spatt, J., 339

Stoltz, J.-F., 1, 147, 237, 287, 879

Streekstra, G.J., 769

Stuart, J., 545

Supparo, I., 105

Talbert, D.G., 93

Temiz, A., 591

Tian-xun, L., 279

Toth, K., 329

Tozzi, E., 203

Tozzi-Ciancarelli, M.G., 203

Trabalzini, L., 797

Trouet, A., S15

Truchot, R.C., 663

Turchetti, V., 797

Uberos, J., 75, 585

Uyesaka, N., 557, 571

Valenzuela, A., 75, 585

Valetitsch, H., 27

Vayá, A., 419

Ventimiglia, G., 393 
Viala, J.L., 637, 643

Vimeux, M., S53

Volpi, L., 709

Walzl, B., 27, 37, 45, 181

Walzl, M., 27, 37, 45, 181

Wang, X., 237, 709

Wautier, J.-L., 63

Wei-yuan, M., 279

Welch, C.R., 93
Wenzel, E., 189

Wessely, P., 339

Wienert, V., S47

Williams, G., 245

Witte, S., 1, 3, 7, 147

Wong, W.J., 723

Yamamoto, J., 509

Yedgar. S., 497

Yoa, R.G., 663
Yong-De, S., 847

Yova, D., 369

Yubero, L., S7

Zeiler, K., 339

Zhao, R.R., 779

Zilow, E.P., 233

Zong-yao, W., 279

Zoukourian, C., 63

Zu-lai, T., 279

Zwaginga, J.J., 769 